\title{
Chemical and microbial quality of whey from cow milk using calf rennet, microbial rennet, lactic acid and papaya latex
}

\author{
MA Islam**, S Sultana\#, MSI Sojib, MSR Siddiki, MF Rahman', MA Mannan², R Jahan ${ }^{3}$ \\ and MS Bari
}

Department of Dairy Science, Bangladesh Agricultural University, Mymensingh-2202, Bangladesh; ${ }^{1}$ Avance Asia Limited, 45, Bir Uttam C.R. Dutta Road, Dhaka, Bangladesh; 'EON Bioscience Limited, Shantospur, Badarganj, Rangpur, Bangladesh; ${ }^{3}$ New Palli, Health Officers Lane, Sankipara, Mymensingh-2202, Bangladesh.

\begin{abstract}
The purpose of the study was to determine the quality of whey obtained from cow milk using different types of coagulants (microbial rennet, calf rennet, lactic acid and papaya latex). The quality of whey was evaluated with the help of chemical and microbial tests. Results revealed that maximum whey yield (765 $\mathrm{mL} / \mathrm{L}$ milk) was obtained from lactic acid coagulation which was $17 \mathrm{~mL}$ higher than that of the microbial rennet coagulation $(p=0.000)$. The $\mathrm{pH}$ was found significantly $(p<0.05)$ higher when the microbial rennet was used as coagulants. Whey obtained by the lactic acid coagulation was superior in terms of chemical quality compared to the whey obtained by coagulating action of other coagulating agents $(p=0.000-$ $0.001)$. Total solids and lactose content was found highest ( $7.2 \%$ and $4.8 \%$, respectively) in lactic acid whey which was significantly higher $(\approx 1 \%)$ than that of the other types of whey $(p=0.000)$. In addition, protein content was also found higher $(p<0.05)$ in whey obtained by lactic coagulation. On the other hand, efficiency of fat and ash recovery in curd was found lowest in calf rennet $(p=0.000)$ among the studied coagulants. However, phosphorus content was highest $(p=0.005)$ in calf rennet whey and the whey obtained by microbial rennet coagulation had the lowest $(p=0.000)$ calcium concentration. Microbial load was found maximum (117 cfu $\times 10^{4} / \mathrm{mL}$ ) in whey drained out in microbial rennet coagulation, whereas, papaya latex whey had the lowest count ( $78 \mathrm{cfu} \times 10^{4} / \mathrm{ml}$ ), and the microbial count of other two whey was intermediate of them $(p=0.000-0.001)$. In general, considering all the quality attributes, lactic acid whey was found better followed by calf rennet and papaya latex. It indicates more nutrient recovery in the curd produced by the microbial rennet.
\end{abstract}

Keywords: Whey, coagulants, microbial rennet, calf rennet, lactic acid, papaya latex

Bangladesh Animal Husbandry Association. All rights reserved.

Bang. J. Anim. Sci. 2021. 50 (2):107-113

\section{INTRODUCTION}

Whey is the watery part of the milk obtained during cheese or curd making which is rich in lactose, minerals, water soluble vitamins and contains lactalbumin and traces of fat (Bylund, 2003). To the western world, it originates from cheese, casein and yoghurt industry whereas, in Bangladesh sweetmeat industry is the main producers. Whey is one of the most promising nutritional by-products of the dairy sector, particularly in the cheese, chhana, sweetmeats, and paneer industries (Islam et al., 2021). The whey presents greenish yellow color and according to Kumar et al. (2016) the $\mathrm{pH}$ of the whey can vary from 4.0 to 6.6 depending on the coagulation types of the milk. From $10 \mathrm{~kg}$ of milk used for the cheese production, almost $9 \mathrm{~kg}$ of whey- the main by product is obtained (Prazeres et al., 2012). Approximately 180 to 190 tons of whey per year was produced worldwide (Mollea et al., 2013), but, unfortunately only about $50 \%$ of this valuable product is utilized into various food and feed products. Rest of the unutilized whey is usually disposed in sewerage, rivers and other water bodies that causes foremost polluting effects on environment (Smithers, 2015). Wastage of this whey causes huge nutritional and economic loses as well. However, environment control regulations are more aware of its cheap disposal directly to the environment owe to both of its high biological and chemical oxygen demand.

Whey proteins are recommended due to their benefits in boosting immunity and lowering the risk of heart disease and cancer (Li et al., 2005). 
Whey has been used to make whey protein concentrate (WPC), whey powder, lactose, lactic acid, whey pastes, and other products all over the world. Opportunities for wide-range applications of whey and whey constituents in the food and animal feed industry has been enhanced due to the presence of several nutritionally important constituents having excellent functional characteristics that improve the nutritional status and immunity of the body. Hence, the development of technology to utilize whey for the manufacture of a variety of new food products as well as for the replacement of comparatively expensive food ingredients is regarded as an important research and development activity of food industry (Mathur and Shahani, 1979). Aslam (2017) prepared a probiotic beverage using whey and orange juice. Islam et al. (2021) also prepared a whey pineapple juice blended probiotic beverage.

Milk processing techniques are the primary determinants of the type and composition of whey. The most common type of whey originates from the cheese manufacturing industry based on coagulating the casein by rennet or by other coagulating enzymes. The use of coagulants other than the calf rennet is attributed to the high demand (compare to the availability) and price of the calf rennet, religious point of view (Islam and Judaism), food habits (e.g. vegetarian) and consumer preference (e.g. organic acids for acid curd and sweetmeats in Indian sub-continent). The major coagulants types are aspartate, serine and cysteine proteases that are different in their proteolytic actions. Finally, leads to the variation in the milk gel formation and thus the drainage to the whey. Cheese composition, nitrogen fractions, degradation pattern of $a_{s 1}$-casein, $\beta$ casein and textural properties during ripening are directly associated with the coagulants used (Sengul, 2014). According to Mamo and Balasubramanian (2008), lipolytic enzymes contained in the rennet extracted from a crude abomasum attributed to characteristic flavor of whey and cheese. Among the different coagulants used, the domain of papaya latex is poor compared to the others and the crude calf rennet has been used since time immemorial for the production of artisanal cheese in different parts of the Bangladesh, especially, in the Ostogram and Kuliarchar of Kishoreganj district. The use of coagulants are found different around the globe depending on the market demand of the types of manufactured dairy product and hence, necessitates the reporting of whey quality in response of the use of different milk coagulant.

Therefore, in this work we attempt to report comparatively the chemical and microbial quality of the whey produced by coagulating the cow milk using calf rennet, microbial rennet, lactic acid and papaya (Carica papaya) latex.

\section{MATERIALS AND METHODS}

\section{Site of the study}

The study was conducted at the Dairy Chemistry and Technology Laboratory, Department of Dairy Science, Bangladesh Agricultural University (BAU), Mymensingh-2202, Bangladesh. In addition, protein test was carried out in the Animal Nutrition Laboratory, BAU and minerals were analyzed in the Agricultural Chemistry Laboratory, BAU.

\section{Collection of fresh milk and coagulants}

Milk (Table 1) was collected from Bangladesh Agricultural University Dairy Farm. Six litters of fresh whole milk were collected for each trial. Preparation of different coagulants are presented in Table 2. An abomasum of a calf of 11 months old was collected from Ostogram, Kishorganj district. Papaya was collected from on campus plantation of BAU. Commercial preparation of lactic acid (Merck, D6100 Darmastadt, F. R. Germany, concentration 90\%) and commercial rennet (Chr. Hansen A/s, Denmark) was also used as coagulant.

\section{Preparation of whey}

The freshly collected milk was heated up to $90{ }^{\circ} \mathrm{C}$, followed by cooling to $40{ }^{\circ} \mathrm{C}$. After that, $2 \%$ undefined composite lactic starter culture was added to the measured amount of milk and kept at $40{ }^{\circ} \mathrm{C}$ for $1 \mathrm{hr}$. After incubation, milk was divided into 4 equal parts ( $\approx 1.2 \mathrm{~L}$ in each part) in different beakers. Calcium chloride solution was added to each beaker @ $0.02 \%$. Followed by mixing and adding calf rennet $100 \mathrm{~mL}$, microbial rennet $10 \mathrm{~mL}$, lactic acid solution $120 \mathrm{~mL}$ and papaya latex $120 \mathrm{~mL}$ to 4 different beakers separately and then waited up to coagulation (Checked by spatula cutting of the curd). After complete coagulation, the curd was cut and whey was drained out by muslin cloth. Then it was kept in refrigerator until further analyses. 
Table 1: $\mathrm{pH}$, acidity (\%), compositional (\%) and microbial features ( $\log \mathrm{cfu} / \mathrm{mL}$ ) of the raw milk.

\begin{tabular}{ll}
\hline Measurements & Quantity \\
\hline $\mathrm{pH}$ & 6.25 \\
Acidity & 0.16 \\
Total solids & 12.7 \\
Protein & 3.34 \\
Fat & 3.56 \\
Calcium & 0.10 \\
Phosphorus & 0.06 \\
Magnesium & 0.04 \\
SPC & 7.00 \\
Coliform & 3.00 \\
\hline
\end{tabular}

*SPC, Standard Plate Count; cfu, Colony forming Unit.

Table 2: Preparation of different types of coagulant.

\begin{tabular}{lll}
\hline $\begin{array}{l}\text { Types } \\
\text { coagulants }\end{array}$ & of & $\begin{array}{l}\text { Preparation } \\
\text { coagulants }\end{array}$ \\
\hline Calf rennet & $\begin{array}{l}750 \mathrm{ml} \text { water }+250 \mathrm{ml} \\
\text { milk }+100 \quad \mathrm{~g} \\
\text { abomasum } \\
\text { overnight) }\end{array}$ \\
Microbial rennet & $\begin{array}{l}1000 \mathrm{ml} \text { water }+7 \mathrm{~g} \\
\text { microbial rennet }\end{array}$ \\
Lactic acid & $\begin{array}{l}120 \mathrm{ml} \text { water+ } 1.5 \mathrm{ml} \\
\text { lactic acid }\end{array}$ \\
Papaya latex & $\begin{array}{l}120 \text { ml water }+6 \\
\text { drops papaya latex }\end{array}$ \\
\hline
\end{tabular}

\section{Chemical tests}

The milk and whey $\mathrm{pH}$ was measured with the help of $\mathrm{pH}$ meter-215 (ciba coming diagnostic limited). Acidity was determined by titrating with N/10 sodium hydroxide. Total solids was determined by oven drying and ash of the samples was determined by the ignition of the oven dried sample in muffle furnace according to AOAC (2004). Fat test was done by Babcock method. Protein was estimated by Kjeldhal method and 6.38 was used to convert the $\mathrm{N}$ into crude protein. Calcium content was assayed by EDTA titrimetric method in the presence of calcon indicator. Phosphorus content was determined by spectrophotometric (TG-80U, Germany) method using $\mathrm{SnCl}_{2}$ as reducing agent and sulphomolybdic acid. The color intensity was measured at $660 \mathrm{~nm}$. EDTA titrimetric method was used for the determination of $\mathrm{Mg}$ concentration in the presence of eriochrome black $\mathrm{T}$ (EBT) indicator.

\section{Microbiological test}

Standard plate count method was used to determine the total bacterial count. The SPC agar (HiMedia, India) was used and the incubation temperature was $34{ }^{\circ} \mathrm{C}$ for $48 \mathrm{hrs}$ in an oven (J. P. SELECTA, Barcelona, Spain). The coliform count was done in a VRB agar (Himedia, India) plate. An incubation temperature of $32{ }^{\circ} \mathrm{C}$ was used for 24 hrs in the oven (J. P. SELECTA, Barcelona, Spain).

\section{Statistical analysis}

The grouping of the recorded variables was done based on coagulants used. All the analyses were done in triplicate. One way ANOVA was obtained from the Minitab 16 where Tukey's test was done for mean separation.

\section{RESULTS AND DISCUSSION}

\section{Yield of whey}

Maximum whey yields $(763-765 \mathrm{~mL} / \mathrm{L})$ were obtained from the calf rennet, lactic acid and papaya latex coagulation of the milk $(p>0.05)$. The yield of whey from the microbial rennet of the milk was significantly $(p=0.000)$ lower $(17 \mathrm{~mL} / \mathrm{L})$ than that of those three coagulants. Jayaprakasha (1992) reported 80 to $90 \%$ whey yield during the cheese or casein preparation on the basis of original milk used. In the present study, we found $74-76 \%$ which is not too far from the report. According to Jelen (1979) $1 \mathrm{~kg}$ cheese production yields 8.7 - $9 \mathrm{~kg}$ of whey production. Hill and Ferrer (2021) and Bylund (2003) also mentioned the similar pattern of whey yield during the cheese production.

\section{pH and acidity}

The average $\mathrm{pH}$ was found 5.48-6.18 in whey using different coagulants. Bund and Pandit (2005) found that $\mathrm{pH}$ content of sweet whey is 5.86.6 which is 4.0-5.0 in acid whey. Yadav et al. (2015) reported a different $\mathrm{pH}$ range of $3.57-4.34$ and 6.02-6.58 for acid and sweet whey, respectively. The most commonly encountered type of whey drained out from manufacture of cheese and/or certain casein products, where the mechanism of processing is based on the casein 
coagulation by the action of rennet. An industrial casein-clotting preparation generally comprising of chymosin or other casein-coagulating enzymes. Walstra et al. (2006) mentioned that the optimum $\mathrm{pH}$ for mozzarella and cottage cheese are $5.2-5.3$ and 4.6 to 4.8 , respectively. So, the requirement of the main product is the pre-determined factor to set the $\mathrm{pH}$ of the whey.

The highest $(0.12 \%)$ acidity content was found when microbial rennet used as coagulant and the lowest $(0.07 \%)$ value was found in calf rennet whey. These are not consistent with the results on $\mathrm{pH}$. Bund and Pandit (2005) reported that acidity content of sweet whey is $0.10-0.20 \%$ and the acid whey was $0.20-0.40 \%$. These results are also different from the present study.

\section{Total solids}

The highest total solids content was found in the lactic acid coagulated whey (7\%) followed by the both of the rennet and papaya latex (6\%). Both the rennet whey's total solids content differ nonsignificantly ( $p>0.05)$. Ganju and Gogate (2017) mentioned that the total solids content of the whey is $5-6 \%$. Gupta (2000) also reported the similar kind of values viz. total solids of whey and Channa whey are $7.0 \%$ and $6.5 \%$, respectively. Here, acid whey appears to be lower which was also reported by Khamrui and Rajorhia (1998) who found 0.3 $0.45 \%$ less total solids in the acid whey than the sweet one. However, Kosikowski (1999) observed $0.15 \%$ higher total solids in acid whey compared to the sweet whey, which was $0.40 \%$ higher than the cheese whey (Bylund, 2003). The different results indicate the importance of milk heating before the coagulation, coagulant amount, rate of addition, coagulation mechanism, whey separation (from the curd) technique etc. in the total solids content of the whey.

Table 3: Chemical composition and microbial load of whey obtained from coagulation of cow milk using different types of coagulant.

\begin{tabular}{|c|c|c|c|c|c|}
\hline Variables & $\begin{array}{l}\text { Microbial } \\
\text { rennet }\end{array}$ & Calf rennet & Lactic acid & Papaya latex & $\begin{array}{c}\text { p- } \\
\text { value }\end{array}$ \\
\hline Yield of whey (mL /L) & $747.67^{b} \pm 2.52$ & $762.67^{a} \pm 2.52$ & $764.67^{a} \pm 2.52$ & $763.00^{\mathrm{a}} \pm 2.00$ & 0.000 \\
\hline $\mathrm{pH}$ & $6.18^{\mathrm{a}} \pm 0.020$ & $5.48^{b} \pm 0.08$ & $5.62^{b} \pm 0.06$ & $6.06^{a} \pm 0.05$ & 0.000 \\
\hline Acidity (\%) & $0.12^{\mathrm{a}} \pm 0.005$ & $0.07^{c} \pm 0.005$ & $0.08^{c} \pm 0.005$ & $0.11^{b} \pm 0.01$ & 0.000 \\
\hline Total solids (\%) & $6.22^{b} \pm 0.030$ & $6.25^{b} \pm 0.02$ & $7.16^{a} \pm 0.03$ & $6.13^{c} \pm 0.02$ & 0.000 \\
\hline Protein (\%) & $0.93^{b} \pm 0.02$ & $0.91^{b} \pm 0.02$ & $0.99^{a} \pm 0.02$ & $0.92^{b} \pm 0.01$ & 0.001 \\
\hline Fat (\%) & $0.50^{\mathrm{b}} \pm 0.10$ & $0.77^{a} \pm 0.03$ & $0.63^{b} \pm 0.01$ & $0.52^{b} \pm 0.03$ & 0.001 \\
\hline $\mathrm{CHO}(\%)$ & $4.26^{b} \pm 0.01$ & $3.96^{d} \pm 0.04$ & $4.83^{a} \pm 0.03$ & $4.13^{c} \pm 0.02$ & 0.000 \\
\hline Ash (\%) & $0.53^{c} \pm 0.02$ & $0.74^{a} \pm 0.02$ & $0.64^{b} \pm 0.02$ & $0.54^{c} \pm 0.02$ & 0.000 \\
\hline Calcium (\%) & $0.06^{b} \pm 0.002$ & $0.09^{a} \pm 0.005$ & $0.09^{a} \pm 0.009$ & $0.08^{\mathrm{a}} \pm 0.005$ & 0.001 \\
\hline Phosphorus (\%) & $0.03^{b} \pm 0.005$ & $0.062^{\mathrm{a}} \pm 0.00$ & $0.04^{b} \pm 0.01$ & $0.04^{b} \pm 0.005$ & 0.005 \\
\hline Magnesium (\%) & $0.01 \pm 0.003$ & $0.02 \pm 0.003$ & $0.02 \pm 0.008$ & $0.02 \pm 0.002$ & 0.173 \\
\hline $\mathrm{SPC}\left(\mathrm{cfu} \times 10^{4} / \mathrm{ml}\right)$ & $117.33^{a} \pm 6.43$ & $91.00^{b} \pm 3.61$ & $44.33^{d} \pm 4.04$ & $77.67^{c} \pm 2.52$ & 0.000 \\
\hline Coliform $\left(\mathrm{cfu} \times 10^{4} / \mathrm{ml}\right)$ & nil & nil & Nil & nil & - \\
\hline
\end{tabular}

Means with the different superscripts in a row differed significantly; SPC, Standard plate count; Cfu, colony forming unit.

\section{Protein content}

The whey obtained from lactic acid coagulation showed significantly $(p<0.001)$ higher crude protein content $(0.99 \%)$ which was $0.06-0.08 \%$ higher than the other three types of whey who among them were found statistically similar ( $p>0.05)$. According to Ganju and Gogate (2017) the protein content of whey may range from 0.80 to $1.0 \%$. Khamrui and Rajorhia (1998) found highest protein in the buffalo milk cheddar cheese whey $(0.98 \%)$ and that of buffalo milk chhana whey was $0.89 \%$. They also observed 0.30 and $0.38 \%$ protein in paneer whey and shrikhand whey, respectively. All others were ranged 
between $0.7-0.9 \%$. All these reported data support the present results and indicates the significance of types of milk used and milk processing from where the whey is obtained.

\section{Fat content}

Calf rennet has the lowest efficiency in the recovery of fat content in cheese as a result highest percent of fat was found $0.77 \%$ in the calf rennet whey whereas, the lowest $(0.50 \%)$ fat percent was found in microbial rennet whey. Khamrui and Rajorhia (1998) found that fat content of sweet whey of cow milk was $0.06 \%$ and buffalo milk was $0.34 \%$. And the acid whey of cow milk was $0.10 \%$ and buffalo milk was $0.10 \%$. Kosikowski (1999) also reported that fat content of sweet whey is $0.5 \%$ and acid whey is $0.04 \%$. All these studies support the result of present study. Bylund (2003) reported $0.05 \%$ fat both in cheese and acid whey, however, Hill and Ferrer (2021) mentioned that $0.04 \%-0.06 \%$ fat in whey after cream separation. These variations are related with several different factors like technologies applied (Aldalur et al. 2019), Milk coagulation properties (Vacca, et al. 2020) and types of cheese (Margolies et al. 2017) or product.

\section{Ash content}

The ash content of different whey differed significantly $(p=0.000)$. Whey from calf rennet coagulation had the maximum $(0.74 \%)$ ash content which is $0.20 \%$ higher than the whey obtained after microbial rennet and papaya latex coagulation and $0.10 \%$ higher than the lactic acid type. Gupta (2000) found that the ash content of sweet whey is $0.60 \%$ and that of the acid whey is $0.70 \%$. On the other hand, Yadav et al., (2015) found $0.61 \%$ ash in the whey. Khamrui and Rajorhia (1998) demonstrated the differences between the milk types and whey types. According to them, the sweet whey obtained from cow and buffalo milk contains $0.59 \%$ and $0.54 \%$ ash, respectively. Which is $0.57 \%$ and $0.44 \%$, respectively for the acid whey. However, all these are in a reasonable range.

\section{Mineral content}

The average calcium content was found 0.06 $0.09 \%$ and phosphorus content was found $0.03-$ $0.06 \%$ in experimental types of whey. Khamrui and Rajorhia (1998) found that the calcium content of sweet whey of cow milk is $0.04 \%$ and buffalo milk is $0.05 \%$. In case of acid whey these are $0.05 \%$ and $0.04 \%$, respectively. They also reported that the phosphorus content of sweet whey of cow and buffalo milk are same $(0.04 \%)$ and buffalo milk acid whey has $0.01 \%$ more phosphorus. All these are in line with the results of the present study. The magnesium content was ranged between 0.01 to $0.02 \%$ which differs nonsignificantly among the whey types. Morr (1984) reported that magnesium content of whey is $0.013 \%$. Bund and Pandit (2005) found the magnesium content of whey as $0.023 \%$. Which also support the result of present study.

\section{Microbiological count}

The maximum standard plate count was observed in microbial rennet whey which was $117.33 \times 10^{4} /$ $\mathrm{mL}$. This was followed by calf rennet whey which is $26 \times 10^{4} / \mathrm{mL}$ less than the microbial rennet whey. Lactic acid whey has a count half of the calf rennet while the papaya latex whey is intermediate of calf rennet and lactic acid whey with $40 \times 10^{4}$ / $\mathrm{mL}$ less value than the microbial rennet whey. Coliform count was found nil in all types of the whey. Deosarkar (2004) reported that Escherichia coli should not be present in a good and wellprepared cheese as high acidity of the fermented product should restrict their survival. Slow acidity development can allow sufficient buildup of $E$. coli to give a "taint" or "off flavour" to this retail product which is a clear indication of gross contamination.

\section{CONCLUSIONS}

This study was conducted to know the chemical composition and microbial quality of whey from fresh cow milk using microbial rennet, calf rennet, lactic acid and papaya latex. Variations were found in the yield of whey and concentration of different milk constituents in the whey including calcium and phosphorus. This indicates the importance of nutrient recovery from the whey and effects of different coagulant in the preparation of milk curd. However, the milk nutrient loss in whey or curd yield and recovery of milk constituents in curd is a multifactor variables and need to consider all to make a conclusive statement.

Acknowledgement: The present work received no fund from any of the organization.

Conflict of Interest: There is no conflict of interest regarding this manuscript. 


\section{References}

Aldalur A, MÁ Bustamante and LJR Barron (2019). Effects of technological settings on yield, curd, whey, and cheese composition during the cheese-making process from raw sheep milk in small rural dairies: Emphasis on cutting and cooking conditions. Journal of Dairy Science, 102: 7813-7825.

AOAC (Association of Official Analytical Chemists) (2004). Official method of analysis. Seventeenth edition, Arlington, Virginia, USA.

Aslam H (2017). Preparation of probiotic beverage using whey and orange juice. MS Thesis, Department of Dairy Science, Bangladesh Agricultural University, Mymensingh, Bangladesh.

Bund RK and BA Pandit (2005). Isolating proteins from whey. Modern Food Processing, 1: 3645.

Bylund G (2003). Whey processing: Dairy Processing Handbook. https://ia904506.us. archive.org/10/items/DairyProcessingHandbo okTetrapak/Dairy-Processing-HandbookTetrapak.pdf accessed on 04 December 2021 at 5:41 pm (BD standard time).

Deosarkar SS (2004). Preparation of lactose hydrolyzed whey beverage. MS Thesis, Anand Agricultural University, Anand, India.

Ganju S and PR Gogate (2017). A review on approaches for efficient recovery of whey proteins from dairy industry effluents. Journal of Food Engineering, 215: 84-96.

Gupta VK (2000). Overview of processing and utilization of dairy by products. Indian Dairyman, 52: 55-59.

Hill AR and MA Ferrer (2021). Cheese Making Technology e-Book. https://books.lib. uoguelph.ca/cheesemakingtechnologyebook/ chapter/7-1-whey-processing/ accessed on 04 December 2021 at 05:37 pm (BD standard time).

Islam MZ, S Tabassum, MH Rashid, GE Vegarud, MS Alam and MA Islam (2021). Development of probiotic beverage using whey and pineapple (Ananas comosus) juice: Sensory and physico-chemical properties and probiotic survivability during in-vitro gastrointestinal digestion. Journal of Agriculture and Food Research, 4: 100144.
Jayaprakasha HM (1992). Membrane processing application for production of whey protein concentrates. PhD Thesis, National Dairy Institute, Deemed University, Karnal, India.

Jelen P (1979). Industrial whey processing technology: An overview. Journal of Agricultural and Food Chemistry, 27: 658-61.

Khamrui K and GS Rajorhia (1998). Making profit from whey. Indian Dairyman, 50: 13-17.

Kosikowski FV (1999). Whey utilization and whey products. Journal of Dairy Science, 62: 11491160.

Kumar N, Vandana and S Hat (2016). The four Fs for whey utilization. Beverage \& Food World, 43: 28-31.

Li CP, H Enomoto, S Ohki, H Ohtomo and T Aoki (2005). Improvement of functional properties of whey protein isolate through glycation and phosphorylation by dry heating. Journal of Dairy Science, 88: 4137-4145.

Margolies B, MC Adams, J Pranata, K Gondoutomo and DM Barbano (2017). Effect of uncertainty in composition and weight measures in control of cheese yield and fat loss in large cheese factories. Journal of Dairy Science, 100: 6822-6852.

Mathur BN and KM Shahani (1979). Use of total whey constituents for human food. Journal of Dairy Science, 62: 99-105.

Mamo A and N Balasubramanian (2018). Calf rennet production and its performance optimization. Journal of Applied and Natural Science, 10: 247-252.

Mollea C, L Marmo and F Bosco (2013). Valorisation of cheese whey, a by-product from the dairy industry. Agricultural Biological Sciences, 33: 549-588.

Morr CV (1984). Production and use of milk proteins in food. Food Technology, 38: 39-48.

Prazeres AR, F Carvalho and J Rivas (2012). Cheese whey management: A review. Journal of Environmental Management, 110: 48-68.

Sengul (2014). Calf rennet production and its performance optimization. Journal of Applied and Natural Science, 10: 247-252.

Smithers GW (2015). Wheying up the options yesterday, today and tomorrow. International Dairy Journal, 48: 2-14. 
Vacca GM, G Stocco, ML Dettori, G Bittante and M Pazzola (2020). Goat cheese yield and recovery of fat, protein, and total solids in curd are affected by milk coagulation properties. Journal of Dairy Science, 103: 1352-1365.

Walstra P, JTM Wouters and TJ Geurts (2006). Dairy science and Technology. 2nd Edn. CRC
Press/Taylor and Francis Group, Boca Raton, USA.

Yadav JSS, S Yan, S Pilli, L Kumar, RD Tyagi and RY Surampalli (2015). Cheese whey: A potential resource to transform into bioprotein, functional/nutritional proteins and bioactive peptides. Biotechnology Advances, 33: 756-774. 